2017 , volume 6 , issue 3

Kobylińska, A., \& Balcerowski, M. (2017). Pension valorization method - selected issues. Copernican Journal of Finance \& Accounting, 6(3), 35-46. http://dx.doi.org/10.12775/CJFA.2017.015

\author{
AnNA KobYLIŃSKA* \\ Warsaw University \\ MaCiej BalCerowski** \\ Instytut Emerytalny
}

\title{
PENSION VALORIZATION METHOD - SELECTED ISSUES
}

Keywords: social security system, pension, fixed valorization, types of valorization, valorization.

J E L Classification: K30.

Abstract: The aim of this article is to present basic terms and issues connected with pension valorization. Within the framework of this paper were presented methods of valorization and development of valorization in time. Particular attention has been paid to the issue of jurisdiction of the Polish Constitutional Tribunal K 9/12 mentioned fixed valorization from 2012. Historical analyze is a measure to determine minimal standards of valorization according to Polish Constitution.

\section{IIITRODUCTION}

Pension benefits are paid in long-term perspective. The assumption is that the fixed pension benefits are to cover the pensioners' economic needs. However, it should be noted that in the functioning market economy the economic value of

Date of submission: December 27, 2017; date of acceptance: December 30, 2017.

* Contact information: anna.kobylinska@student.uw.edu.pl, Warsaw University, Krakowskie Przedmieście 26/28, 00-927 Warsaw, Poland, phone: +48 225520 000; ORCID ID: https://orcid.org/0000-0003-4501-8768.

** Contact information: maciek.balcerowski@gmail.com, Instytut Emerytalny Sp. z o.o., Solec 38 lok. 204, 00-394 Warsaw, Poland; ORCID ID: https://orcid.org/00000001-6282-3238. 
established benefits will decrease. This results primarily from the progressive inflation. The decrease of the economic value over time poses one of the threats occurring in case of failure to introduce the benefit instrument valorization. It is also important to determine the risk of formation of the so-called old portfolios and lack of beneficiaries' participation in the increase of the social wealth.

The threats mentioned above allow to take a stand on the essential meaning of legal regulations related to pension benefit valorization. The importance of valorization can be demonstrated by the fact that it is regulated both by national law and by acts of international law.

\section{METHODOLOGY OF THE ARTICLE}

The main issue of the article is to present legal aspects of valorization. As a part of the article it authors mentioned about economic aspects of the applied methods of valorization. Primary scientific method used by the authors of the article is formal-dogmatic analyze of the legal acts and historical analyze of pre-existing legal acts. Authors also applied methods of economic law analysis.

\section{CONCEPT OF VALORIZATION}

The valorization concept comes in two basic meanings. Firstly, it appears on the basis of art. 358 [1] of the Civil Code in the context of an exception to the principle of nominalism in force in the Polish civil law. Secondly, it appears on the basis of the Act on pensions and annuities in the content of Art. 89, as a system rule in which pension benefits are subject to regular valorization. The doctrine has repeatedly examined the admissibility of the use of the civil law valorization institution of social security benefits. It should be noted, however, that the final position was taken in the context of which those regulations do not apply (i.a. Antonów, 2014, p. 495-496; Zieliński, 1994, p. 200). In view of the uniform position of the doctrine in this regard, these views will be analyzed more broadly.

When analyzing the valorization institution defined in the Act on pensions and annuities, it is necessary to focus on its function of updating the amount of pension benefits in accordance with the provisions of the relation to changes in the level of living costs or salaries (Gudowska \& Ślebzak, 2013, p. 591). This problem should also be linked to the concept of substitution rate. By that, the relationship between income earned by the beneficiary before retirement and 
the amount of the pension should be understood. Valorization is to allow maintaining at least the original replacement rate in terms of acquiring power of the benefits.

Apart from maintaining the economic value of the benefits granted, valorization may also be an instrument of social policy of the state in enabling the beneficiaries to participate in the GDP growth (Antonów, 2003, p. 141). The characteristic feature of valorization is its systemic character distinguishing it from the ad hoc valorization (Gudowska \& Ślebzak, 2013, p. 591-592).

\section{TYPES OF VALORIZATION}

There are three main types of valorization distinguished in the doctrine of social insurance law: price valorization, pay valorization and mixed valorization (Jędrasik-Jankowska, 2016, p. 166).

The first of above mentioned valorization s assumes an increase of the pension benefit amount based on the current inflation ratio, i.e. the money purchasing power decrease value index. In case of price valorization, the existing pension value is increased by the inflation rate. This can be expressed with the following formula:

$E z=E+E x W i$

Where:

Ez - pension benefit upon valorization,

E - pension benefit prior to valorization,

$\mathrm{Wi}$ - inflation ratio expressed in percentage value.

For example, assuming that the inflation ratio is $3 \%$, whereas the amount of pension prior to valorization was PLN 1000, the pension subject to valorization by the inflation ratio will be PLN 1030. In the market economy one can also see the phenomenon of deflation, i.e. increase of the money value. In such a case, within the framework of price valorization, the amount of the benefit is not changed.

Pay valorization, as an index of increase of pension benefits, applies the GDP (gross domestic product) growth ratio. The pension value in such a case is in- 
creased by the amount of the GDP growth expressed in percentage value. This can be expressed with the following formula:

$$
E z=E+E x W P K B
$$

Where:

Ez - pension benefit upon valorization,

E - pension benefit prior to valorization,

WPKB - GDP growth ratio expressed in percentage value.

For example, assuming a 4\% GDP growth, with the amount of pension prior to valorization of PLN 1000, such a pension would be PLN 1040 upon wage valorization. In case of GDP value decrease, wage valorization is not applied.

The last type of valorization is the so-called mixed valorization, sometimes also referred to as price-wage valorization. It assumes the use of both the inflation ratio and the GDP growth ratio. They can be taken into consideration to different extents. This can be expressed with the following formula:

$$
E z=E+E x W i x W 1+E x W P K B \times W 2
$$

Where:

Ez - pension benefit upon valorization,

E - pension benefit prior to valorization,

$\mathrm{Wi}$ - inflation ratio expressed in percentage value,

WPKB - GDP growth ratio expressed in percentage value,

W1, W2 - inflation ratio consideration index or GDP growth ratio expressed in percentage value.

For example, assuming the inflation level of 3\%, GDP growth of $4 \%$, where the amount of pension prior to valorization was PLN 1000, and where W1 and W2 indices are $80 \%$ and $20 \%$, respectively, the amount of pension will be PLN 1038.

The third type currently adopted in the system is the price-wage (mixed) valorization, introduced by the Act on pensions and disability pensions (APDP). It assumes establishment of the pension amount by multiplication of the benefit amount and its assessment base by the so-called valorization ratio, i.e. the 
goods price index in the previous calendar year increased by at least $20 \%$ of the average wage increase. Until 2015, this increase was the subject of negotiations of the Trilateral Commission for Social and Economic Issues [Trójstronna Komisja do Spraw Społeczno-Gospodarczych]; in 2015, under the Act of 24 July 2015 on the Council of Social Dialogue [Rada Dialogu Społecznego] and other social dialogue institutions it was, however, transformed in the Council of Social Dialogue. If the Council does not adopt a resolution regarding the above subject in a reasonable time, the increase shall be determined by way of a decree of the Council of Ministers.

In relation to received pensions and disability pensions, the valorization is carried out ex officio (Antonów, 2009, p. 497). According to Art. 88 of APDP, the pensions and disability pensions are subject to annual valorization as of 1 March. However, the price-wage valorization mechanism, with assumption of change of the annual benefit amount, was not the only solution functioning in the social insurance system over the years.

\section{HISTORICAL DEVELOPMENT OF THE VALORIZATION INSTITUTION IN POLAND}

The valorization institution understood as a system solution was introduced in the polish legal system by way of the Act of 14 December 1982 on pension benefits for employees and their families (Journal of Laws 1982 No 50 item 267). The above-mentioned Act entered into force on 1986. Prior to introduction of the Act on pension benefits for employees and their families, ad hoc re-valorization activities were carried out. It resulted from the assumption that the problem of price amount change is insignificant in a socialist economy. However, it turned out that introducing such a long vacatio legis forced the introduction of an additional re-valorization of the benefits even before the Act entered into force. The Act of 1982 introduced temporary valorization based on the wage index.

The introduced valorization system can be evaluated positively from the point of view of protecting the economic interests of the beneficiaries of the pension system. This may be proven by the fact that while in 1989-1996 the real remuneration value decreased by $26 \%$ in case of pensions, it was only $6 \%$ (Antonów, 2003, p. 149). The consequence of the existing valorization system was a significant encumbrance of public finances.

In consequence, it was necessary to revise the applicable valorization system. This change was introduced by the Act of 29 September 1995. The Act as- 
sumed resigning from the wage valorization model and replacing it with price valorization. This solution was to allow to balance the situation of public finances, simultaneously maintaining the real economic value of paid pensions. However, the consequence of the introduced valorization model was the farreaching limitation of pensioner participation in the GDP growth.

As a result, the current Act of 17 December 1998 was passed on pensions and annuities from the Social Insurance Fund (Journal of Laws 162, item 1118). The Act assumes establishing a mixed valorization of pension benefits scheme. The current standard of valorization of pension and annuities benefits has been shaped by the Act amending the Act on pensions and annuities of the Social Insurance Fund dated 7 September 2007. (Journal of Laws No. 191 item 1368). According to the mentioned Act, the annual valorization model was adopted, and as the index of valorization, the average annual price index of consumer goods and services increased in the preceding calendar year by at least $20 \%$ of the real increase of the average remuneration in the preceding calendar year. By setting the minimum valorization standard, the legislator allowed the possibility of raising the level of participation of beneficiaries in the GDP growth by introducing negotiations within the Council for Social Dialogue. Subsequent amendments to article 89 of the Act on pensions and annuities has not made any significant changes to the current valorization model.

\section{"FIXED" VALORIZATION}

It is worth to shed some light on so-called fixed valorization introduced in the act dated 13 January 2012 amending the act on disability and retirement pensions from the Social Insurance Fund (Journal of Laws of 2012, item 118) (hereinafter referred to as "UEIR"). The said valorization is based on the idea of oneoff increase of the retirement benefits by the uniform amount of PLN 71 and the valorization of the benefit assessment basis by the valorization index corresponding to the percentage increase of the disability or retirement pension. In this case, the legislator has withdrawn from the application of the valorization model stipulated in the Article 89 of UEIR. This solution raised a lot of doubts as due to the majority of the legal doctrine valorization minimum standard is determined by the price valorization allowing the economic value of the benefit to be maintained (Szpor, 2013, p. 155). If the said minimum standard is not provided, the risk of the devaluation of the paid benefits and - in consequence - the loss of their economic value would occur (Jędrasik-Jankowska \& Jankowska, 
2011, p. 188). The introduction of the valorization of the disability and retirement pensions by the uniform amount resulted in the following phenomenon: in relation to some benefits not only was the benefit replacement rate maintained but it also increased at the same time. Nevertheless, the adopted valorization model assumed that in case of the persons who receive the highest benefits the level of the price valorization has not been reached. Hence, it should be assumed that in such a case the benefit replacement rate has been decreased. In conclusion, the adopted valorization model gave a certain preference to those having lower pension benefits at the expense of people receiving higher benefits (Gudowska \& Ślebzak, 2013, p. 597).

The valorization model introduced in the act of 2012 was widely discussed by the Constitutional Court. Not meeting the standards of the price valorization in relation to the part of the beneficiaries was one of the main problems indicated in the application raising the issue of the constitutionality of the act of 2012. Moreover, it was argued that UEIR did not bear in mind the existence of the principle of benefits equivalence applicable within the retirement pension system. Despite the allegations raised, in case No. K 9/12 dated 19 December 2012, the Constitutional Court decided on the constitutionality of the act in question ${ }^{1}$. The Constitutional Court's decision was supported by three principal theses which will be briefly described below.

Firstly, it was assumed that the introduced fixed valorization was pursuing the objective of the social solidarity, i.e. increase of the retirement benefits of the persons receiving the lowest benefits. The Constitutional Court also questioned the violation of the principle of benefits equivalence in relation to the selected social groups, such as soldiers or public officers.

Secondly, it was underlined that the purpose of the right to old- age security, as well as to benefits valorization, is to ensure the minimum of the subsistence level. Therefore, a possible breach of the right to old- age security may occur if the valorization below the level of the price valorization leads to reduction of economic value of the pension as a result of the fixed valorization.

Furthermore, the Constitutional Court stressed that the UEIR was of the episodic nature. Hence, it was not the UEIR's intention to introduce totally different valorization system which would turn out to be less favorable for part of the insured persons.

${ }^{1}$ It should be noted that six dissenting opinions have been communicated in relation to the judgment No. K 9/12 dated 19 December 2012. 
Undoubtedly, the abovementioned judgment of the Constitutional Court constitutes an exemption to the existing jurisprudence which underlines the importance of the valorization in the process of the maintenance of the paid retirement benefits economic value (for instance see the ruling of the Constitutional Court dated 20 December 1999, No. K 4/99, OTK 1999, No. 7, item 65 and the ruling of the Constitutional Court dated 15 October 1997, OTK 1997, No. 3-4, item 39). Additionally, some doubts may arise over the arguments indicated in the ruling's justification. It seems that the Constitutional Court depreciates the principle of the benefits equivalence in terms of the retirement benefits giving priority to the principle of social solidarism. The Constitutional Court rightly points out that the amount of the retirement benefits received by the soldiers or public officers does not depend on the amount of the premium deducted. This results from the fact that the retirement benefits in the given case are paid under the social provision system which does not require the premium payment. However, it should be noted that the amount of the received retirement benefit usually depends on the period of service of the soldier or public officer or on the specific service conditions. Taking the above into account, it seems that the equivalence of the retirement benefits should also apply to other factors. Such a conclusion seems to be rational due to the fact that the equivalence of the retirement benefits in relation to the retirement benefits paid under the defined benefits scheme has not been argued by the legal doctrine. The amount of the benefit under the defined benefits scheme depended, among others, on the insurance period (Jędrasik-Jankowska, 2016, p. 148).

The Constitutional Court's arguments regarding the problem of ensuring the minimum of the subsistence level may be questionable in terms of realization of the main scope of the valorization which is the maintenance of the economic value of the paid benefits. Although, the Constitutional Court rightly indicates that the fixed valorization does not cause the decrease of the benefits' amount below of the subsistence level, it does lead to decrease of the replacement rate in case of the beneficiaries receiving the highest benefits.

Furthermore, decrease of the replacement rate problem is strictly connected with the third argument presented in the Constitutional Court's ruling, i.e. the episodic nature of the analyzed act. UEIR does not introduce the new valorization model. It was agreed that the legal consequences resulting from the act were limited in time up to one calendar year. However, it should be noted that, in fact, the introduced fixed valorization resulted in the change of the benefits' and replacement rate's value. Therefore, although the fix valorization mech- 
anism was used only once and in relation to the specific time period its consequences (e.g. change of the replacement rate) are of lasting nature. What is more, the following valorization s performed due to the Article 89 of UEIR did not restore the consequences resulted from the fixed valorization.

\section{ECONOMICAL RESULTS OF 'FIXED' VALORYZATION}

As we could see 'fixed' valorization was based on the idea of one-off increase of the retirement benefits by the uniform amount of 71 PLN. It means that index of valorization was different for pensioners depends from amount of pension. Below we will try to present economical results of 'fixed' valorization on the example of two pensions - where one is 1000 PLN and second is 3000 PLN in the period of five years. According to The Polish Social Insurance Institution index of valorization were:

Table 1. Rate of valorization 2012-2016

\begin{tabular}{|c|c|c|c|}
\hline \hline Year & Index of valorization & Rate of inflation & GDP growth \\
\hline \hline 2012 & $104.68 \%$ & $3.7 \%$ & $1.9 \%$ \\
\hline 2013 & $104.54 \%$ & $0.9 \%$ & $1.6 \%$ \\
\hline 2014 & $102.06 \%$ & $0 \%$ & $3.4 \%$ \\
\hline 2015 & $105.37 \%$ & $-0.9 \%$ & $3.6 \%$ \\
\hline 2016 & $106.37 \%$ & $-0.6 \%$ & $2.7 \%$ \\
\hline \hline
\end{tabular}

S o u r c e : Polish Social Insurance Institution, Central Statistical Office, Polish Market.

Index of valorization for 2012 is a average value for a whole group of pensioners. Index of valorization for retiree with benefit 1000 PLN would be in 2012 on the level of $107.1 \%$ and for retiree with benefit 3000 PLN on the level of $102.37 \%$.

If legislator would not decide for 'fixed' valorization in 2012 the first benefit in 2016 would be on amount of 1251.81 PLN and the second one in amount of 3755.43 PLN. Adoption of 'fixed' valorization results that first benefit in 2016 would be on amount of 1280.75 PLN and the second one on amount of 3672.43 PLN. It shows us that in the long term 'fixed' valorization is resulting in higher benefits for retiree with smaller pensions and lower benefits for retiree with higher pensions. 


\section{CONCLUSIONS}

The pension is kind of benefit which is paid in a long term. It results in susceptibility for inflation and the issue of the "old wallets". By the concept of the old wallets we understand pensions which were granted prior and they are lower than pensions which are granted nowadays. Enrichment of the society also is the starting point of the discussion about participation of the retirement in GDP increase by increasing their pensions.

Constitutional basis of social insurance system is article 67.1 of Constitution of the Republic of the Poland. According to this regulation a citizen shall have the right to social security whenever incapacitated for work by reason of sickness or invalidism as well as having attained retirement age. The scope and forms of social security shall be specified by statute. The doctrine of the social insurance point out that valorization as a measure which guarantee the economic value of the pension is an important part of the right to social security (Banaszak, 2012, s. 407; Gudowska \& Ślebzak, 2013, s. 591). Without such guarantee granted benefits would depreciate and have only symbolic significance. It would be most important during the period of high inflation.

Despite that right to valorization of the pension is the part of the right to social security the Constitution is not providing us clear guidelines which method of valorization should be picked by legislator (Safjan \& Bosek, 2016, p. 1519; for instance see the ruling of the Constitutional Court dated 8 of May 2000r. SK 22/99, OTK $2000 \mathrm{Nr} 4$ poz. 107). It seems that according to current legislation the legislator has to choose which method of valorization would be applied. The legislator does not have complete freedom in that matter. He is obliged to respect minimal standards of valorization which are defined in jurisdiction of Constitutional Tribunal and the established view of the doctrine.

The issue of the valorization is important task to deal by state social policy and policy itself. Mentioned legislator right to create rules of the valorization might result in creation 'special acts' which could be used as a way to achieve political goals. It can cause serious danger for stability of pension system. B. Banaszak said that social insurance and especially pension insurance should be free from legislator actions motivated by political reasons (Banaszak, 2012, p. 406).

Right to social security and right to valorization could be limited by other constitutional rights or rules. The main importance have social solidarity rule and sustainability of public finances. Legislator is also obliged to take into con- 
sideration rule of equivalence of the benefits of the insured and pension benefits. The term of insured benefits should be understand widely not only as paid contributions.

Binding valorization model have to meet indicated above rules and rights which can also be contradictory. We should agree with prevailing view of the doctrine which says that minimal standard of the valorization create the pay valorization (Szpor, 2013, p. 155; Jończyk, 2006, p. 152). Mentioned method provide to preserve economical value of the pension and its equivalence to insured benefits. Increasing replacement rate by pay valorization is strictly connected with social solidarity rule which give to pensioners right to participate in GDP increase. Increasing of the pension due to pay valorization demand from the legislator to respect rule of sustainability of public finances. If legislator choose too 'expensive' method of valorization the state would not be able to fulfill its obligations.

\section{REFERENCES}

Act amending the Act on pensions and annuities of the Social Insurance Fund dated 7 September 2007. (Journal of Laws No. 191 item 1368).

Act of 14 December 1982 on pension benefits for employees and their families (Journal of Laws 1982 No 50 item 267).

Act of 17 December 1998 on pensions and annuities from the Social Insurance Fund (Journal of Laws 162, item 1118).

Act of 23 April 1964 Civil Code (Journal of Laws 2017 item 459).

Act of 24 July 2015 on the Council of Social Dialogue (Journal of Laws 2015 item 1240). Antonów, K. (2003). Prawo do emerytury. (Right to pension.) Cracow: Wolters Kluwer.

Antonów, K. (Ed.) (2009). Ustawa o emeryturach i rentach z Funduszu Ubezpieczeń Społecznych. (Pension from Social Security Fund Act. Commentary.) Warsaw: Oficyna Wydawnictwo.

Antonów, K. (Ed.) (2014). Emerytury i renty z FUS. Emerytury pomostowe. Okresowe emerytury kapitałowe. Komentarz. (Pension from Social Security Fund. 'Bridgining' pension. Periodic capital pensions. Commentary.) Warsaw: Wolters Kluwer.

Banaszak, B. (2012). Konstytucja Rzeczpospolitej Polskiej. Komentarz. (Constitution of the Republic of Poland. Commentary.) Warsaw: C.H. Beck.

Central Statistical Office, http://stat.gov.pl/obszary-tematyczne/ceny-handel/wskazniki-cen/wskazniki-cen-towarow-i-uslug-konsumpcyjnych-pot-inflacja-/rocznewskazniki-cen-towarow-i-uslug-konsumpcyjnych-w-latach-1950-2014/ (accessed: 28.01.2018). 
Gudowska, B., \& Ślebzak, K. (Eds.) (2013). Emerytury i renty z Funduszu Ubezpieczeń Społecznych. Emerytury pomostowe. Komentarz. (Pension from Social Security Fund. 'Bridging' pensions. Commentary. Commentary.) Warszawa: C.H. Beck.

Jędrasik-Jankowska, I. (2016). Pojęcia i Konstrukcje prawne ubezpieczenia społecznego. (Terms and legal institutions of social insurance.) Warsaw: Wolters Kluwer.

Jędrasik-Jankowska, I., \& Jankowska, K. (2011). Prawo do emerytury. Komentarz do ustaw z orzecznictwem. (Right to pension. Acts commentary with judicature.) Warszawa: LexisNexis.

Jończyk, J. (2006). Prawo zabezpieczenia społecznego. (Right to social security.) Cracow: Zakamycze.

Polish Market, http://www.polishmarket.com/Poland_Basic_Data.shtml (accessed: 28.01.2018).

Polish Social Insurance Institution, http://www.zus.pl/wskazniki-waloryzacji-rocznej (accessed: 28.01.2018).

Safjan, M., \& Bosek, L. (Eds.) (2016). Konstytucja RP. Tom I. Komentarz. Art. 1-86. (Constitution of the Republic of Poland. Volume 1. Commentary. Article 1-86.) Warsaw: C.H. Beck.

Szpor, G. (Ed.) (2013). System ubezpieczeń społecznych. Zagadnienia podstawowe. (System of social insurance. Basic issues.) Warsaw: LexisNexis.

Zieliński, T. (1994). Ubezpieczenia społeczne pracowników. Zarys systemu prawnego część ogólna. (Employee's social insurance. Basics of legal frame-general part.) Warsaw-Cracow: Wydawnictwo Naukowe PWN. 